\title{
HOAX: PEMANFAATANNYA SEBAGAI BAHAN EDUKASI DI ERA LITERASI DIGITAL DALAM PEMBENTUKAN KARAKTER GENERASI MUDA
}

\author{
Muncar Tyas Palupi \\ Universitas PGRI Yogyakarta \\ muncartyas@gmail.com
}

\begin{abstract}
ABSTRAK
Artikel ini berisi ide bahwa sebenarnya hoax dapat dimanfaatkan untuk bahan edukasi di era literasi digital terutama dalam pembentukan karakter generasi muda. Pesatnya perkembangan teknologi informasi membawa berbagai dampak di semua lini kehidupan. Dampak yang pertama dan terutama adalah terjadinya perubahan cara hidup di dalam masyarakat. Masyarakat lebih banyak memanfaatkan teknologi informasi dalam keseharian hidupnya. Alat komunikasi yang murah dan di dalamnya sudah bisa dipakai untuk mengakses internet sangat mempermudah masyarakat untuk memperoleh berbagai informasi dari dunia luar. Memanfaatkan hoax sebagai bahan edukasi dalam era literasi digital diharapkan akan membuat masyarakat berpikir kritis, lebih bijaksana dalam menyaring dan menyikapi informasi sehingga dapat berpartisipasi dan memberi kontribusi bagi perdamaian dan persatuan bangsa.
\end{abstract}

Kata Kunci: Hoax, Edukasi, Literasi Digital, Pembetukan Karakter

\section{ABSTRACT}

This article contains the idea that hoax can actually be used for educational materials in the era of digital literacy, especially in shaping the character of the younger generation. The rapid development of information technology brings various impacts on all lines of life. The first and foremost impact is a change in the way of life in society. More people use information technology in their daily lives. Communication tools that are inexpensive and can already be used to access the internet make it very easy for people to obtain various information from the outside world. Utilizing hoax as educational material in the era of digital literacy is expected to make people think critically, more wisely in filtering and responding to information so that they can participate and contribute to peace and national unity.

Keywords: Hoax, Education, Digital Literacy, Character Correction

\section{PENDAHULUAN}

Masa revolusi industri 4.0 seperti saat ini, era digital memberikan atmosfer baru di dalam kehidupan manusia. Era tersebut menciptakan gaya baru dalam mengakses informasi dan berkomunikasi. Manusia bisa dengan mudah dan leluasa menelusuri dunia maya hanya dengan bermodalkan kuota internet dan ponsel pintar/gawai (gadget). Pengaksesan informasi mulai berpindah dari media konvensional beralih ke media digital. Beralih ke media digital dirasa sangat menguntungkan karena informasi dapat diperoleh dengan cepat (aktual). Aribowo E.K dalam Retnatiti (ed.) (2017:78) menjelaskan bahwa kecepatan akses informasi tersebut menyebabkan terkadang informasi yang beredar adalah informasi mentah yang tidak disunting dan diverifikasi 
dengan kebenaran informasinya terlebih dahulu. Sehingga, masyarakat menjadi linglung atau 'kebingungan' ketika berita fakta dan yang bohong ber-seliweran silih berganti dengan begitu cepatnya. Gejala tersebut di atas dikenal dengan istilah kejutan budaya (culture shock).

Saat ini di Indonesia sedang marak terjadi peristiwa penyebaran berita palsu atau yang disebut hoax. Peristiwa penyebaran hoax ini menimbulkan keresahan masyarakat di Indonesia, banyak pihak yang merasa dirugikan atas beredarnya hoax tersebut. Hal ini dikarenakan pesatnya perkembangan teknologi yang membuat masyarakat semakin mudah mendapatkan informasi apa pun dari berbagai aplikasi media sosial diantaranya Whatsapp, Instagram, dan LINE. Media sosial tersebut adalah media yang sering dipergunakan oleh pihak-pihak yang mempunyai kepentingan khusus dalam upaya menyebarkan hoax.

Data pengguna internet dari APJJI tahun 2019 yang disurvei di bulan Maret-April dari total populasi sebanyak 264 juta jiwa penduduk Indonesia, ada sebanyak 171,17 juta jiwa atau sekitar 64,8 persen yang sudah terhubung ke internet. kontribusi terbesar atas pengguna internet di Indonesia berasal dari Pulau Jawa yang mencapai 55 persen dari total keseluruhan. Pulau Sumatera berada di posisi kedua dengan pengguna internet sebanyak 21 persen. Banyaknya pengguna internet di Indonesia ini adalah sesuatu hal yang baik karena sebagian besar penduduk Indonesia terbukti sudah mengenal teknologi internet. Akan tetapi dari pengguna sebanyak itu tidak semua adalah orang yang mampu memilah informasi. Sehingga terkadang informasi yang belum jelas kebenarannya ditelan mentah-mentah diyakini sebagai informasi yang benar dan kemudian disebarluaskan.

Seiring perkembangan zaman dan teknologi, pengaruh media komunikasi dan informasi harus memberikan pendidikan yang baik khususnya pada anak bangsa. Dibutuhkan nilai-nilai pendidikan karakter untuk membentengi anak bangsa dari pengaruh negatif dari internet. Pendidikan karakter bukanlah hal yang baru di dunia pendidikan. Pendidikan karakter ini adalah upaya untuk membangun karakter anak bangsa. Pendidikan karakter sangat penting dilakukan karena bangsa Indonesia membutuhkan individu yang handal, bermoral, cerdas, beretika, dan kompetitif dalam menghadapi dunia global. Kementerian Pendidikan Nasional Republik Indonesia menetapkan ada 18 butir pendidikan karakter.

Banyaknya pengguna internet yang mengakrabi literasi digital dan maraknya penyebaran hoax inilah yang menggugah penulis untuk menyampaikan bahwa berita hoax bisa dimanfaatkan sebagai bahan edukasi untuk pembentukan karakter generasi muda. 


\section{LANDASAN TEORI}

Hoax (dalam bahasa Indonesia dituliskan hoaks) adalah informasi yang direkayasa untuk menutupi informasi sebenarnya, dengan kata lain hoax merupakan upaya pemutarbalikan fakta menggunakan informasi yang meyakinkan tetapi tidak dapat diverifikasi kebenarannya (Septanto, 2018:157). Berita bohong atau yang lebih dikenal dengan sebutan hoax didefinisikan sebagai kebohongan yang dibuat secara sengaja untuk menyamarkan kebenaran yang ada (Macdougall dalam Aribowo, 2017: 78). Di dalam KBBI daring, hoaks diartikan: (1) tidak benar, bohong (tentang berita, pesan, dan sebagainya); (2) berita bohong. Rahadi (2017:68) menjelaskan bahwa hoax adalah suatu tipuan yang digunakan untuk mempercayai sesuatu yang salah dan seringkali tidak masuk akal yang disebarkan melalui media online. Jadi hoax adalah berita tipuan pemutarbalikan fakta yang dibuat dengan sengaja.

Bahan edukasi adalah istilah yang saya samakan artinya dengan media edukasi dan lazimnya disebut dengan media pembelajaran adalah berbagai jenis komponen dalam lingkungan siswa yang dapat merangsangnya untuk belajar (Gagne dalam Sadiman, 2012: 6). Azhar Arsyad (2006: 2) mengutip pendapat Gerlach \& Ely (1971) yang menjelaskan bahwa media adalah manusia, materi, atau kejadian yang membangun kondisi yang membuat siswa mampu memperoleh pengetahuan, keterampilan atau sikap. Jadi media pembelajaran adalah segala sesuat, bisa berwujud manusia, benda, atau peristiwa yang bisa membantu siswa untuk memperoleh pengetahuan, menghasilkan keterampilan, dan perubahan sikap. Hoax yang disebarkan secara online adalah salah satu bahan edukasi yang bisa dimanfaatkan untuk materi membaca, dalam hal ini adalah membaca kritis (critical reading).

Selanjutnya, pemahaman tentang digital di era generasi 4.0 perlu didasari dengan adanya pengetahuan mengenai literasi. Literasi digital secara singkat dipahami sebagai sebuah aktivitas mencerdaskan generasi (muda) untuk mampu memahami dan menyikapi secara positif kehadiran peranti canggih dalam berbagai format yang sudah menjadi bagian kehidupan sehari-hari yang kreatif dan produktif (Gislter, 1997:1-2), (Alkali, 2004), (Belshaw, 2012).

Pendidikan karakter adalah terminologi yang dipunyai oleh setiap negara. Undang-Undang Sistem Pendidikan Nasional No.20 Tahun 2003 pasal 1 butir 1, pendidikan adalah: "usaha sadar dan terencana untuk mewujudkan suasana belajar dan proses pembelajaran agar peserta didik secara aktif mengembangkan potensi dirinya untuk memiliki kekuatan spiritual keagamaan, pengendalian diri, kepribadian, kecerdasaan, akhlak mulia, serta keterampilan yang diperlukan dirinya, masyarakat, bangsa dan Negara." 
Pendidikan nasional bertujuan: "untuk mengembangkan potensi peserta didik agar menjadi manusia yang beriman dan bertakwa kepada Tuhan Yang Maha Esa, berakhlak mulia, cakap, kreatif, mandiri, dan menjadi warga negara yang demokratis serta bertanggung jawab" (UU Sisdiknas No. 20 tahun 2003 pasal 3). Pendidikan karakter berpijak dari karakter dasar manusia, yang bersumber dari nilai moral universal (bersifat absolut) sebagai pengejawantahan nilai-nilai agama yang biasa disebut the golden rule. Pendidikan karakter dapat memiliki tujuan yang pasti, apabila berpijak dari nilai-nilai karakter dasar tersebut (Setiyawati, 217: 348). Pada dasarnya, pendidikan karakter berusaha menciptakan insan yang cinta kepada Allah dan ciptaan-Nya (alam dengan isinya), bertanggung jawab, jujur, hormat dan santun, penuh kasih sayang, peduli, bisa bekerjasama, percaya diri, kreatif, kerja keras, pantang menyerah, adil, baik, rendah hati, penuh toleransi, cinta damai dan cinta persatuan.

Hoax sebagai bahan edukasi, literasi digital, dan pendidikan karakter akan diuraikan di bawah ini. Pembahasan akan menggunakan metode deskriptif kualitatif, yaitu dengan menjelaskan data-data yang diperoleh melalui studi pustaka kemudian menguraikannya menjadi paparan-paparan yang empiris untuk memperoleh simpulan. Pembahasan akan dibagi menjadi tiga bagian, yaitu pembahasan tentang pemanfaatan hoax sebagai bahan edukasi membaca kritis, literasi media, serta pendidikan karakter yang ingin diperoleh dan dipertahankan untuk generasi muda.

\section{PEMBAHASAN}

\section{Pemanfaatan Hoax sebagai Bahan Edukasi Membaca Kritis}

Hoax atau berita palsu dapat dilontarkan melalui berbagai media. Jenisjenis hoax tersebut dapat diklasifikasi dalam berbagai bentuk. Hidaya, dkk. (2019:8-9) menjelaskannya sebagai berikut.

a. Berita bohong (fake news) merupakan berita yang berusaha menggantikan berita yang asli. Tujuan berita ini dibuat untuk memalsukan atau memasukkan ketidakbenaran dalam suatu berita. Penulis biasanya menambahkan hal-hal yang tidak benar dan teori persengkokolan, makin aneh, makin baik.

b. Tautan jebakan (clickbait), adalah jebakan yang dibuat dengan membuat tautan dalam suatu situs.. Tujuannya adalah untuk menarik orang yang sedang membuka suatu situs, agar masuk ke situs lainnya. Isi atau konten di dalam tautan ini sesuai fakta akan tetapi judulnya dibuat berlebihan dan sering pula dipasang gambar yang menarik untuk memancing pembaca. 
c. Bias konfirmasi (confirmation bias) adalah kecenderungan untuk menginterpretasikan kejadian yang baru terjadi sebaik bukti dari kepercayaan yang sudah ada.

d. Ketidakbenaran informasi (misinformation), merupakan informasi yang tidak benar atau tidak akurat, yang ditulis tujuannya untuk menipu.

e. Satire, adalah tulisan yang menggunakan humor, ironi, dan hal yang dilebih-lebihkan untuk mengkomentari kejadian yang sedang hangat.

f. Pasca-kebenaran (Post-truth) adalah kejadian yang mengedepankan penonjolan emosi, sehingga untuk membentuk opini publik, emosi lebih berperan daripada fakta.

g. Propaganda, adalah kreativitas penyebarluasan informasi, fakta, argumen, gosip, setengah-kebenaran, atau bahkan kebohongan untuk mempengaruhi opini publik.

Berbagai jenis hoax tersebut sudah terbukti banyak menimbulkan hal-hal negatif dalam kehidupan bermasyarakat. Sudah pasti, setiap berita palsu ada yang merencanakan, menulis, dan menyebarkan. Tindakan tersebut merupakan sebuah proses yang digunakan untuk tujuan tertentu, yaitu membentuk opini publik terhadap seseorang, situasi, atau kejadian tertentu.

Ciri-ciri hoax yang paling menonjol adalah adanya ketidakjelasan siapa penulisnya, tokoh, waktu, dan tempat peristiwa terjadinya (karena tidak bisa dilacak). Biasanya hoax mengangkat informasi yang aktual yang sedang menjadi perbincangan di masyarakat. Penekanan lebih pada isu sara sehingga diharapkan mudah melecut emosi. Bahasa yang digunakan sangat provokatif dan berpesan kepada pembaca untuk men-share, me-like, meng-klik dengan beberapa kalimat yang berlebihan, misalnya "Jika anda seorang muslim klik...", "Jangan lupa like \& share di atas yaa, semoga ikhtiar kebaikan anda menjadi pemberat amal...", "Share tulisan ini agar keluarga anda tidak menjadi korbannya..." dan lain sebagainya. Selain itu, ciri lainnya adalah isi dari hoax adalah beritanya tidak berimbang cenderung menyampaikan fakta dan pertimbangan yang berat sebelah, menyudutkan pihak tertentu. Selain yang sudah disebutkan di atas, hoax juga tidak mencantumkan siapa penulisnya atau sumber penulisannya. Isi hoax selain berupa informasi politik, banyak juga ditemukan pemberitaan dalam kaitannya dengan isu bencana alam, tips pengobatan dan kesehatan bahkan keagamaan. 
Penggunaan media sosial sebagai sarana penyebaran hoax memang sangat efektif. Namun, di sisi lain penggunaan media sosial untuk menyebarkan hoax menunjukkan munculnya sikap-sikap tidak bertanggung jawab. Para pelaku dapat dikatakan sebagai orang-orang yang tidak mempunyai keberanian dan kekuatan menghadapi seseorang, masyarakat, lingkungan tertentu, dan situasi tertentu. Walaupun begitu, media sosial seperti Whatsapp dan lain sebagainya memang memanjakan para 'pecundang' untuk melakukan tindakan menyebar dan menebar berita palsu.

Penyebaran hoax tidak dapat dicegah ataupun diberantas secara tuntas walaupun undang-undang ITE sudah menerapkan rambu-rambu sanksi bagi penyebar. Untuk itu, penyikapan terhadap hoax perlu dilakukan dengan mengedukasi masyarakat pengguna media sosial supaya tidak menjadi korban.

Banyak kejadian dicatat sebagai hasil penyebarluasan hoax. Media massa seperti televisi dan surat kabar memberitakan kejadian-kejadian, seperti penggalangan massa untuk tujuan berbau politis dan sara. Baru-baru ini terjadi isu penghinaan terhadap etnis tertentu yang mengakibatkan kekacauan besar dari Jawa sampai ke Papua. Hoax tersebut sengaja dihembuskan untuk tujuan memecah belah kesatuan bangsa Indonesia.

Tidak lepas dari ingatan kita, munculnya berita-berita palsu yang semakin menyudutkan mantan gubernur Jakarta, Basuki Tjahaja Purnama sewaktu didakwa menodai agama pada tahun 2016. Berita-berita seputar penodaan keagamaan dibesar-besarkan, sehingga menyulut kemarahan sebagai ujungnya. Hal ini merupakan post truth, atau kejadian yang menyulut emosi yang sudah tidak lagi berdasarkan pada berita yang tersebar.

Dalam ranah politik tertinggi pun tak luput dari hoax adalah seputar sosok capres dan cawapres, Joko Widodo serta Mahruf Amin pada Pilpres 2019. Berita paling hangat adalah seputar aksi demo mahasiswa menuntut pengesahan RKUHP dan pembatalan RUU KPK. Aksi demo yang digelar oleh ribuan mahasiswa dan dihadang oleh petugas keamanan menjadi bahan hoax yang empuk, seperti berita mahasiswa dipukuli oleh polisi dalam aksi demo tersebut. Penyebutan korban tewas yang tidak berdasarkan data. Belum lagi hoax yang mengatasnamakan lembaga-lembaga tertentu, seperti Lembaga survey, Lembaga BMKG yang mengabarkan kegentingan gunung serta bencana alam yang sedang mengancam penduduk. Selain itu, hoax seputar penculikan anak yang merajalela, pembunuh yang bergentayangan, dan lain sebagainya. Itu adalah fake news, berita bohong yang berujung keresahan masyarakat dan saling curiga.

Hoax yang disebarkan wujudnya beraneka macam, tidak hanya dalam bentuk tulisan, tetapi juga gambar, slogan, ilustrasi, dan wujud-wujud visual lain. Terkadang jika masyarakat jeli berita-berita tersebut terlihat janggal, tidak masuk 
akal, dan terkesan dipaksakan. Ini adalah bukti bahwa hoax disebarkan melalui media sosial. Berita di media sosial adalah saluran penyebaran terbesar pertama, sedangkan aplikasi chatting merupakan saluran penyebaran terbesar kedua (Septanto, 2018:159). Hoax biasanya mengerucut pada penggalangan rasa kebencian, teror ketakutan, dan sara. Dengan mengetahui hulu tujuan hoax tersebut, diperlukanlah edukasi yang benar dan tepat menyikapi media-media yang berkembang dengan pesat, yang sebenarnya disiapkan untuk membantu kehidupan manusia supaya lebih mudah.

Menyaring hoax bukanlah hal mudah. Informasi yang diterima bisa saja 'ditelan' mentah-mentah. Hal ini disebabkan kurangnya bersikap kritis terhadap hal yang masih baru. Kembali lagi semua bergantung dari edukasi yang diberikan. Peran pendidik inilah yang yang sangat dibutuhkan untuk mengatasinya. Ajarilah bagaimana cara membaca kritis (critical reading). Jadi bukan sekadar membaca teks, tapi tidak memahami seluruh isi bacaan. Membaca kritis adalah kemampuan memahami makna tersirat sebuah bacaan. Untuk itu, diperlukan kemampuan berfikir dan bersikap kritis.

Dalam membaca kritis inilah, pembaca mengolah bahan bacaan secara kritis. (cf.Harris et. Al. 1983; smith, 1986; Albert dalam Tarigan, 1988:89). Agustina dalam Utami, dkk (2012:140) menjelaskan bahwa membaca kritis adalah membaca yang bertujuan untuk mengetahui fakta-fakta yang terdapat dalam bacaan dan kemudian memberikan penilaian terhadap fakta itu. Pembaca tidak sekedar menyerap yang ada, tetapi ia bersama-sama penulis berpikir tentang masalah yang dibahas. Nurhadi (1989:59) menyatakan bahwa membaca kritis merupakan kemampuan seorang pembaca mengolah bahan bacaan secara kritis untuk menemukan keseluruhan makna bacaan, baik makna tersirat maupun tersurat, melalui tahap mengenal, memahami, menganalisis, mensintesis dan menilai. Salah satu bahan edukasi untuk membaca kritis ini bisa memanfaatkan hoax.

Budaya literasi secara kritis atau budaya memahami tulisan perlu ditingkatkan sehingga dapat menjadi tameng untuk mengedukasi generasi muda. Maksudnya adalah pentingnya memahami bacaan dengan mengetahui 6 poin penting pada suatu bacaan, yaitu $5 \mathrm{~W}+1 \mathrm{H}$, yang kemudian dipahami, dianalisis, disintesis, dan dinilai.

\section{Literasi Media}

Literasi Media dipahami sebagai sebuah pemelekpengetahuan terhadap keadaan yang dihadapi generasi muda dan cara penyikapannya. Lebih jelasnya, literasi media merupakan sikap peduli masyarakat terhadap efek negatif media 
(Silvana dan Cecep, 2018:149). Salah satu dampak yang diharapkan dari literasi media adalah berkurangnya sikap-sikap individualis seseorang yang berdampak negatif. Dampak negatif tersebut dapat berupa semakin meningkatnya sikap individualis, potensi kriminal melalui media, serta overload dalam komunikasi.

Tujuan dasar literasi media adalah mengajarkan pengguna media untuk dapat dan mampu menganalisis pesan yang disampaikan oleh media massa. Kemudian pengguna media diharapkan mampu mempertimbangkan apa tujuan komersial dan politik dibalik citra atau pesan media tersebut dan menganalisa siapa yang bertanggung jawab atas pesan atau ide yang berimplikasi pesan atau citra” khusus "itu (Silvana dan Cecep, 2018:149). Di abad ke-21 ini, literasi digital sebagai penyongsung era generasi 4.0 merupakan sebuah keniscayaan untuk disikapi.

Literasi digital merupakan salah satu bagian dari literasi media. Dijelaskan olah Kurniawati dan Baroroh (2012), literasi digital adalah sikap ketertarikan dan kemampuan individu dalam menggunakan teknologi digital yang berupa alat komunikasi untuk mengakses, mengelola, mengintegrasikan, menganalisis dan mengevaluasi informasi, membangun pengetahuan baru, membuat dan berkomunikasi dengan orang lain agar dapat berpartisipasi secara efektif dalam masyarakat.

Pola pendidikan karakter bagi generasi milenial dapat menggunakan literasi digital sebagai sarananya. Generasi milenial dbiasakan untuk mengumpulkan informasi dan mengelola informasi yang didapatnya secara efektif. Dengan cara membiasakan mengasah keterampilan literasi digital, anakanak milenial dapat belajar bagaimana cara memiliki karakter damai. Mengelola informasi dengan tidak menerima secara mentah informasi yang didapatnya, tidak asal menerima dan menyebarluaskan hoaks, serta membangun pengetahuan baru yang lebih efektif, sehingga generasi milenial mampu memberikan kontribusi bagi perdamaian dan persatuan bangsa.

Sementara itu, Belshaw (2012) dalam Silvana (2018:150) mengatakan bahwa ada delapan elemen esensisal dalam upaya mengembangkan literasi digital, yaitu (1) Kultural, yaitu pemahaman ragam konteks pengguna dunia digital, (2) kognitif, yaitu daya pikir dalam menilai konten, (3) Konstruktif, yaitu reka cipta sesuatu yang ahli dan aktual, (4) Komunikatif, yaitu memahami kinerja, jejaring dan komunikasi di dunia digital, (5) Kepercayaan diri yang bertanggung jawab, (6) Kreatif, yaitu melakukan hal baru dengan cara baru, (7) Kritis dalam menyikapi konten dan literasi digital sebagai kecakapan hidup, serta (8) bertanggung jawab secara sosial.

Literasi media mempunyai banyak poin tutorial, namun pelaksanaannya memerlukan tenaga-tenaga pembimbing yang berpengalaman. Komunitas- 
komunitas anak muda, seperti sanggar bermain, sanggar menari, sanggar sastra, sanggar menggambar atau animasi, kegiatan ilmiah remaja, pramuka, pecinta alam, dan lain sebagainya merupakan kantong-kantong kegiatan kepemudaan yang sangat potensial diberikan wawasan dan pelatihan literasi media. Kantongkantong kegiatan tersebut sekaligus menjadi wadah apresiasi dan kreasi meramu kecanggihan media digital.

\section{Pendidikan Karakter}

Hoax adalah bahan edukasi yang mempunyai manfaat besar bagi pembentukan karakter generasi muda tentunya melalui pendidikan karakter. Megawangi (2007:93) memaparkan bahwa pendidikan karakter adalah usaha untuk mendidik anak agar dapat mengambil keputusan dengan bijak dan mengaplikasikan hal tersebut dalam kehidupan sehari-harinya. Oleh karenanya mereka dapat memberikan sumbangsih yang positif kepada lingkungan sekitarnya. Nilai-nilai karakter yang perlu diajarkan kepada anak-anak adalah nilai-nilai universal yang berlaku untuk seluruh agama, tradisi, dan budaya. Meskipun berbeda latar belakang budaya, suku, dan agama, nilai-nilai universal itu harus dapat menjadi perekat bagi seluruh warga masyarakat. Penguasaan terhadap nilai-nilai karakter itu disebut dengan kecerdasan moral.

Ada berbagai cara untuk membangun kecerdasan moral. Borba (2008: 4) menjelaskan bahwa kecerdasan moral adalah kemampuan seseorang untuk memahami hal yang benar dan yang salah, yakni memiliki keyakinan etika yang kuat dan bertindak berdasarkan keyakinan tersebut, sehingga ia bersikap benar dan terhormat. Sebagai upaya untuk menumbuhkan karakter yang baik dalam diri anak, Borba memaparkan bahwa bisa dilakukan dengan memberikan penanaman tujuh kebajikan utama (karakter mulia), yaitu: empati, hati nurani, kontrol diri, rasa hormat, kebaikan hati, toleransi, dan keadilan. Ketujuh macam kebajikan tersebutlah yang dapat membentuk manusia berkualitas di mana pun dan kapan pun. Inti dari emosi moral yang membantu anak memahami perasaan orang lain adalah empati. Kebajikan ini membuat anak menjadi peka terhadap kebutuhan dan perasaan orang lain, sehingga terdorong untuk menolong orang yang kesusahan atau kesakitan, serta membuatnya untuk memperlakukan orang lain dengan penuh kasih sayang.

Sedangkan hati nurani adalah suara hati yang menuntun anak untuk memilih jalan yang benar daripada jalan yang salah sehingga anak tetap berada di jalur yang bermoral; Ia akan merasa bersalah ketika melakukan sesuatu yang menyimpang dari jalur yang semestinya. Sedangkan yang dapat membantu anak agar dapat menahan dorongan dari dalam dirinya dan selalu berpikir sebelum bertindak, sehingga ia selalu melakukan hal yang benar, dan kecil kemungkinan 
mengambil tindakan yang berakibat buruk adalah kontrol diri. Kebajikan kontrol diri inilah yang membantu anak menjadi mandiri karena ia tahu bahwa dirinya bisa mengendalikan tindakannya sendiri. Sifat ini akan memunculkan sikap murah hati dan baik hati karena ia mampu menyingkirkan keinginan memuaskan dirinya sendiri serta mengutamakan orang lain.

Kebajikan yang lain adalah rasa hormat. Rasa hormat inilah yang mendorong anak untuk bersikap baik dan menghormati orang lain. Kebajikan ini mengarahkannya untuk memperlakukan orang lain seperti ia ingin diperlakukan oleh orang lain. Rasa hormat mencegahnya untuk bersikap kasar, memperlakukan tidak adil, dan memusuhi. Hak-hak serta perasaan orang lain akan diperhatikannya. Kebajikan yang membantu anak menunjukkan kepeduliannya terhadap kesejahteraan dan perasaan orang lain adalah kebaikan hati. Dengan kebaikan hati, anak akan semakin berbelas kasih terhadap orang lain, tidak memikirkan dirinya sendiri. Ia menyadari perbuatan baik sebagai tindakan yang benar. Anak mampu menghargai perbedaan kualitas dalam diri orang lain, membuka diri terhadap pandangan dan keyakinan baru, dan menghargai orang lain tanpa membedakan suku, gender, penampilan, budaya, agama, kepercayaan, kemampuan, atau orientasi seksual adalah kebajikan yang bernama toleransi.

Dengan toleransi, ia akan memperlakukan orang lain tanpa membedabedakan, baik, dan penuh pengertian. Permusuhan, kekejaman, dan kefanatikan ditentangnya. Anak akan menghargai orang-orang karena karakter mereka. Keadilan menuntun anak agar memperlakukan orang lain dengan baik, tanpa memihak, dan adil. Ia mematuhi aturan, sadar untuk bergiliran dan berbagi, serta mau mendengarkan semua pihak secara terbuka sebelum memberikan penilaian apa pun. Munculnya keinginan untuk membela orang lain yang diperlakukan tidak adil dan menuntut setiap orang agar diperlakukan sama setara (Borba, 2008: 7-8). Tujuh kebajikan tersebutlah yang menjadi pola dasar dalam membentuk karakter. Untuk mendasarinya perlu dilatih dan diterapkan dalam kehidupan sehari-hari. Dengan demikian, seseorang akan berkualitas sebagai insan yang berakhlak mulia atau memiliki kecerdasan moral.

Melalui penekanan nilai-nilai karakter, masifnya pengaruh hoax pada generasi bangsa dapat ditekan dengan maksimal. Penanaman pendidikan karakter pada generasi muda harus diperkuat. Karakter positif seperti sabar, cermat, menghargai orang lain, kemudian nasionalime, pantang menyerah, religius dan karakter positif lainnya menjadi kekuatan dalam menyikapi hoax dengan bijak dan hati-hati. Keteladanan masyarakat dalam menyikapi hoax sangat diperlukan oleh kita semua. Selain sebagai salah satu bentuk proses pendidikan, 
keteladanan yang positif juga merupakan bentuk interaksi positif yang bisa membentuk budaya positif bangsa guna menangkal hoax di segala lini kehidupan.

Sudah menjadi kewajiban semua pihak untuk belajar dan meningkatkan kepekaan terhadap fenomena yang terjadi di lingkungan sekitar, agar bersikap selektif dalam memperoleh berita serta bersikap dewasa dalam menanggapi dan menyikapi adanya hoax. Kemudian, sebagai lingkungan masyarakat pembelajar yang berkarakter positif, masyarakat harus selalu belajar agar mampu menangkal berita hoax dan mampu menyikapi dengan bijak segala berita yang berpotensi memecah belah persatuan dan kesatuan agar mampu menginspirasi generasi penerus bangsa menjadi generasi yang cerdas, bermoral serta unggul dalam karya yang peka terhadap majemuknya bangsa ini.

\section{PENUTUP}

Hoax selalu ada di dalam setiap kehidupan selama manusia hidup dan mempunyai keinginan untuk berkompetisi satu sama lain. Seiring perkembangan zaman, penyebaran berita palsu semakin canggih, dengan memanfaatkan berbagai media massa yang ada. Berita palsu atau hoaks ditujukan untuk membangun opini publik tanpa ada penanggung jawabnya. Hal ini sudah pasti membawa akibat negatif dalam sistem kekerabatan masyarakat. Setiap budaya dalam suatu masyarakat mempunyai logika dan kekuatan untuk mengantisipasi berbagai pengaruh negatif yang muncul.

Salah satu tujuan kehidupan berkerabat adalah terbentuknya karakter individu dalam sebuah masyarakat yang mampu merefleksikan prilaku positif dan tindakan baik yang dapat diwariskan kepada anak cucu. Edukasi menghadapi setiap hoax adalah salah satu cara yang harus tetap dipertahankan dan dikembangkan untuk menyikapi penyebaran hoax yang mengiringi perkembangan teknologi. Edukasi yang memanfaatkan hoax melalui pembelajaran membaca kritis ini dapat digunakan dalam proses pembentukan karakter generasi muda.

\section{DAFTAR PUSTAKA}

Aribowo, E. K. 2017. "Menelusuri Jejak Hoaks dari Kacamata Bahasa: Bagaimana Mendeteksi Berita Palsu Sedini Mungkin," in Retnatiti, S., Rosyidah, dan Bukhori, H. A. (ed.) Literasi dalam Pembelajaran Bahasa. Malang: Universitas Negeri Malang, hal. 78-87.

Arsyad, Azhar. 2006. Media Pembelajaran. Jakarta: PT. Rajagrafindo Persada. 


\section{Jurnal Skeripta, Volume 6 Nomar I, Maret 2020 - PBSI UPY}

Borba, Michele. 2008. Membangun Kecerdasan Moral: Tujuh Kebajikan Utama Agar Anak Bermoral Tinggi. Terj. oleh Lina Jusuf. Jakarta: PT. Gramedia Pustaka Utama.

Gislter.1997. Digital Literacy. New York: Wiley.

Kompas.com. 16 Mei 2019. "APJII: Jumlah Pengguna Internet di Indonesia Tembus 171 JutaJiwa", https://tekno.kompas.com/read/2019/05/16/03260037/apjiijumlah pengguna-internet-di-indonesia-tembus-171-juta-jiwa.

Megawangi, Ratna. 2007. Pendidikan Karakter Solusi Yang Tepat Untuk Membangun Bangsa, Cet. II. Jakarta: Indonesia heritage Foundation.

Nasution, Muhammad Arsad.2017. Hoax Sebagai Bentuk Hudud Menurut Hukum Islam. Padangsidumpuan: IAIN Padangsidumpuan.

Rahadi, Dedi Rianto. 2017. “Perilaku Pengguna Dan Informasi Hoax Di Media Sosial Dedi Rianto Rahadi” dalam Jurnal Manajemen dan Kewirausahaan, Vol 5 No 1.

Sadiman, Arief S, dkk. 2012. Media Pendidikan. Jakarta: Raja Grafindo Persada.

Silvana, Hana, Cecep.2018. Pendidikan Literasi Digital di Kalangan Usia Muda di Kota Bandung. Pedagogia: Jurnal Ilmu Pendidikan. Universitas Pendidikan Indonesia.

Septanto, Henri. 2018. Pengaruh HOAX dan Ujaran Kebencian Sebuah Cyber Crime Dengan Teknologi Sederhana di Kehidupan Sosial Masyarakat. Kulbiscientia. Jurnal Sains dan Teknologi. Volume 5 nomor 2, Agustus 2018.

Setiyawati, Nanda Ayu. 2017. Pendidikan Karakter Sebagai Pilar Pembentuk Karakter Bangsa. Prosiding Seminar Nasional Tahunan Fakultas Ilmu Sosial Universitas Negeri Medan. Vol.1. no. 1. 2017. Hal 348-352.

Utami, Yesi Setya, Ellya Ratna, dan Wirsal Chan. 2012. "Hubungan Kemampuan Membaca Kritis Dengan Kemampuan Menulis Argumentasi Siswa Kelas XI SMAN 1 Kinali" Jurnal Pendidikan Bahasa dan Sastra Indonesia, Vol. 1 No. 1 September 2012; Seri B 87 - 166 